\title{
A tribute to Helen M. Ranney
}

$\mathrm{H}$ elen Ranney, research and clinical hematologist extraordinaire, pioneering chair of medicine, professional society president, and soaring intellect, passed away on April 5, 2010, just a week before her 90th birthday (Figure 1).

Helen was born and raised on a dairy farm in upstate New York to parents who encouraged her to seek a professional career. Helen's mother was also raised on a farm in upstate New York and was encouraged by her mother to attended teachers' school, ultimately working in the same oneroom schoolhouse that Helen had attended for five years in order to send Helen and her brother to college.

While setting out in pre-law studies at Barnard College, Helen soon found she liked working with people and "fixing what you studied" and therefore redirected her efforts toward pre-medical studies. Though she was admitted to New York University School of Medicine, Helen had her heart set on Columbia University College of Physicians and Surgeons but was initially refused admission. Instead, Helen sought out research training at Columbia with Donovan McCune, who inspired her lasting interest in medical research. With the arrival of World War II and with McCune's strong support, Helen was admitted to Columbia, where she also completed her residency in internal medicine.

After completing her clinical training, Helen studied biochemistry with Irving London, focusing her newly developed laboratory skills on her patients with blood diseases. In 1953, Helen determined how to use paper electrophoresis to separate normal hemoglobin ( $\mathrm{Hgb}$ ) from abnormal $\mathrm{Hgb}$ and used this to identify mixed Hgbs in the relatives of children with sickle cell anemia, laying the foundation for clinical testing for this and other hemoglobinopathies. Helen also described the association and disassociation of Hgb subunits, pointing out that the isolated subunits' affinity for oxygen was far greater than that of the intact molecule and lacked the oxygen-binding cooperativity so vital for physiological Hgb function. She was the first to show that $\mathrm{Hgb} \mathrm{C}$ and $\mathrm{Hgb} \mathrm{S}$ are allelic, laying the groundwork for our understanding of $\mathrm{Hgb} \mathrm{SC}$ disease. Helen was also the first to study the association of abnormal Hgbs and the erythrocyte membrane. For these and other scientific and medical achievements, Helen was awarded the Martin Luther King Medical Achievement Award in 1972.

Helen's work next took her to the faculty of the newly developing Albert Einstein College of Medicine, at which she created the "Heredity Clinic." Following a short sojourn at the State University of New York in Buffalo, Helen was recruited to the UCSD in 1973, as chair of medicine, the first female chair of a university department of medicine. That year was doubly good for Helen, as she was elected to the National Academy of Sciences. During

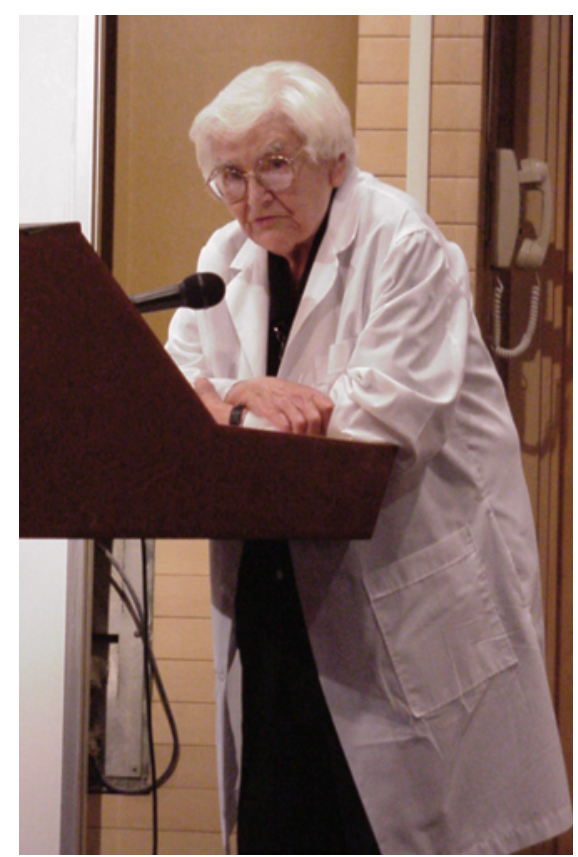

Figure 1

Helen M. Ranney

her tenure at UCSD, Helen led the department to scientific and clinical excellence. She also played important roles on the national academic stage, serving as the first female president of the American Society of Hematology and of the Association of American Physicians. Helen then served as the first female "Distinguished Physician" of the Veterans Affairs medical centers, and upon retirement, the Helen M. Ranney Chair was established, the first endowed chair at UCSD named after a female professor. Helen's career was marked by her intelligent approach to both clinical and research issues, her ability to achieve and inspire greatness, and her incredible wit. It is my great honor and privilege to serve as the Helen M. Ranney Professor, arguably the very best perk available to the chair of our department.

Helen was first and foremost, independent. Her upbringing instilled in her a strong sense of responsibility and the importance of working with her own hands. Helen much preferred doing the experiments herself, "tinkering with the machines," than to have the technicians or post-doctoral fellows simply present her the findings. Helen was also iconoclastic. Helen hated to write review articles; when asked why, she replied, "Ech! It isn't anything original you did. You're writing up a summary derived from your own or other people's work that's been published before." When asked whether her early achievements allowed her to be considered a hematologist, she replied, "Oh, no, no, no, I always considered myself a doctor." And when considering her contributions to medical science, Helen quipped that, "everything that any of us did - if we hadn't done it, it would have been done some years later by somebody else; we're not Bach, who, had he not lived, the music would never have been written."

Helen M. Ranney has served as a role model for countless women and men of medicine and science, all attempting to emulate her warmth, teaching style, inquisitiveness, and impact on her field. She inspired many to take on the great responsibility of leadership and to carry on the tradition of innovation in medicine. I'll always remember her as an intelligent, witty, and inventive mover and shaker in American academic medicine.

\section{Kenneth Kaushansky}

Helen M. Ranney Distinguished Professor, Department of Medicine, UCSD, San Diego, California, USA. E-mail: kkaushansky@ ad.ucsd.edu. 